\title{
ESTIMATION OF SOME METALLIC POLLUTANTS IN DRINKING WATER OF SOME POULTRY FARMS AT ASSIUT GOVERNORATE
}

\author{
MANAL M. SAYED and HOSSAM M. OMAR \\ * Animal Health Research Institute, Assuit Lab. \\ ** Physiology Lab, Zoology Department, Faculty of Science, Assiut University, Assiut 71526, Egypt \\ Email: monna2004@yahoo.com
}

\begin{tabular}{ll}
\hline & ABSTRACT \\
\hline Received at: 8/9/2013 & To estimate the levels of some chemical pollutants (nitrite and some heavy metals) \\
& in drinking water of some poultry farms in Assiut governorate, ninety \\
& representative water samples were collected from different poultry farms at Assiut \\
Accepted: 8/10/2013 & governorate (Dairut, Elkosya, Mnfalute, Abnob, Elfath, Elbadary, Banygalb, \\
& Sahel selem and Abotig). Ten water samples were taken from each localities. \\
& Estimation of lead, cadmium and manganese was done by using Graphite atomic \\
& absorption spectrometer. Estimation of nitrites was done calorimetrically. There \\
& was an increase in the mean levels of lead in water samples collected from poultry \\
& farms at all examined areas. The lead levels in all analyzed water samples were \\
& more than the permissible limit recommended by WHO (0.01ppm). Cadmium \\
& levels in all examined water samples were below the permissible limit \\
& recommended by United States Environmental Protection Agency (US EPA) \\
& (0.005ppm). Manganese levels were between the highest desirable level 0.05 mg/1 \\
& recommended by US EPA and the maximum permissible level 0.5 mg/I \\
& recommended by WHO. The mean levels of nitrite in water samples collected \\
& from poultry farms of Dairut, Elfath, and Sahel selem were exceed the permissible \\
& limit ( 1 mg/L) recommended by the US EPA. The adverse health effect due to \\
exposure of this pollutants were discussed.
\end{tabular}

Key words: Metallic pollutants, Poultry farms, Assiut governorate

\section{INTRODUCTION}

Water pollution is one of the major problems confronting health officials every where, particularly in an expanding industrial economy. One of the less desirable by-products of an industrialized society is the increase of heavy metal accumulation in the environment (Salem et al., 2001).

Industrial wastes, geo-chemical structure and mining create potential sources of heavy metal pollution in the aquatic environment. Under certain environment conditions metals may accumulate to toxic concentration and cause ecological damage (Ozmen et al., 2004).

Lead is one of the most toxic pollutants in the society, it has multiple toxic effects in human body and is a probable human carcinogen. Also lead toxicity cause changes in the nervous system, cardiovascular, reproductive, and immune systems (Taupeau et al., 2001). Lead toxicity induced hematological, gastrointestinal and neurological dysfunction in mammals (Lockitch, 1993).

Douglas -Stroebel et al. (2004) studied the effect of lead-contaminated sediment and nutrition on mallard duckling brain growth and biochemistry found that lower brain weight and ATP (Adenosine triphosphate) concentration than controls but higher concentrations of reduced glutathione (GSH) and calcium.

Cadmium is considered to be the most problematic of the heavy metals. It is a cumulative toxic element that is mainly deposited in the liver and kidneys. Its levels increase throughout life because its biological halflife is 10-30 years. In duck the higher dietary Cd level greatly hypertrophied the liver, kidneys, and greatly reduced gonadal mass in males produced no sperm. It greatly impair the health and reproductive capacity of ducks (Hughes et al., 2000).

Chronic cadmium toxicity causes growth retardation, impaired kidney function, poor reproductive capacity, hypertension, tumor formation, hepatic dysfunction, poor lactation and teratogenic effect. Cadmium accumulates in the soft tissues at all concentration levels down to $0.1 \mathrm{mg} / \mathrm{l}$ in drinking water resulting in anemia, poor metabolism, possible adverse arterial changes in the liver. (Salem et al., 2001).

Excess of manganese (in ground or surface waters) causing permanent brain damage and physical and or personality disorders that are irreversible. Chronic manganese toxicity in humans causes (manganism), 
affecting the CNS and psychic and neurological disorders. Nephritis, liver cirrhosis, anorexia, muscular fatigue and leucopenia are the symptoms of manganism (Massive feeding of manganese to experimental animals retards growth and causes calcium loss and poor absorption of iron which leads to anemia, negative phosphorus balance and rickets (Salem et al., 2001).

Contamination of drinking water with nitrate is a global problem (Spalding and Exner, 1993). Sources of nitrate contamination are organic animal wastes and contamination from septic sewer systems, especially in wells less than 100 feet deep (Eckhardt and Stackelburg, 1995). Ingestion of nitrate and nitrite under conditions likely to form nitroso compounds (NOCs), called endogenous nitrosation, is considered probably carcinogenic to humans and animals (Mary et al., 2008). Excess of nitrite and nitrate in drinking water of poultry cause decreased in feed intake and egg production as well as increase in mortality of hens (Van der Rijt, 1989).

Nitrate and nitrite produced adverse reproductive effects in experimental animals, but these occurred mostly at extremely high levels of exposure, and most of the studies were conducted with nitrite. Nitrate is converted to nitrite in the body and the latter is responsible for the formation of methemoglobin in the blood lead to anemia (Anna and Valerie, 1996).

The need to maintain clean water for both humans and animals has become a major, even a critical concern. Although natural water is one of the purest compounds known, it is difficult to find a source of fresh water that has not been disturbed by man (Marquita, 1997).

The present work aimed to screen the levels of some chemical pollutants (nitrite and some heavy metals) in drinking water of some poultry farms in Assiut governorate and evaluate their health risk.

\section{MATERIALS and METHODS}

Ninety representative tap water samples were collected from different poultry farms at Assiut governorate (Dairut, Elkosya, Mnfalute, Abnob, Elfath, Elbadary, Banygalb, Sahel selem and Abotig) (ten water samples from each locality). Each sample (100 ml water) was taken in one liter clean washed glass container. The containers were twicely washed with the water to be tested before sampling. All water samples were directly transported into the laboratory, shaken well and used as undigested water for analysis of lead, cadmium, manganese and nitrites.

Estimation of lead, cadmium and manganese was done by using Graphite atomic absorption spectrometer ZEEnit $700 \mathrm{P}$ analytikjena (Germany) at the central lab in the faculty of Veterinary MedicineAssiut University according to the method of Szkoda and Zmudzki (2005).

Estimation of nitrites was done according to (Ding et al., 1988) as follow:

One $\mathrm{ml}$ of diluted water sample in deionized water was mixed with a $100 \mu \mathrm{l}$ of Griess reagent $(1: 1, \mathrm{v} / \mathrm{v}$, of N-1-naphthyl-ethylenediamine $0.1 \%$ in distilled $\mathrm{H}_{2} \mathrm{O}$ and sulfanilamide $1 \%$ in $5 \% \mathrm{H}_{3} \mathrm{PO}_{4}$ ) in a test tube and incubated at room temperature for $10 \mathrm{~min}$. Absorbance at $550 \mathrm{~nm}$ was measured calorimetrically, using diluted Griess reagent as a blank. The nitrite concentration was calculated from a precalibrated standard curve using $\mathrm{NaNO}$, as a standard

Statistical analysis: Statistical analysis was carried out by analysis of variance (ANOVA) and the results were compared using student $t$ test. All statistical tests were performed using Graph pad Software Package (Graph pad software, Inc, San Diago CA. USA 1990).

\section{RESULT}

The mean levels of lead in water samples collected from poultry farms at Dairut, Elkosya Manfalute, Abnob, Elfath, Banygalb, Elbadary, Sahel selem and Abotig were $0.37 \pm 0.30,0.096 \pm 0.02,0.26 \pm 0.10$, $0.09 \pm 0.06,0.091 \pm 0.01,0.26 \pm 0.21,0.33 \pm 0.31$, $0.70 \pm 0.30$ and $0.75 \pm 0.32 \mathrm{ppm}$ respectively (table $1)$.

The mean levels of cadmium in water samples collected from poultry farms at Dairut, Elkosya, Manfalute, Abnob, Elfath, Banygalb, Elbadary, Sahel selem and Abotig were 0.0015 $\pm 0.0010,0.0007 \pm$ $0.0002, \quad 0.001 \pm 0.0005, \quad 0.0006 \pm 0.0002$, $0.0004 \pm 0.0002, \quad 0.001 \pm 0.0003, \quad 0.0032 \pm 0.003$, $0.004 \pm 0.002$ and $0.0008 \pm 0.0004 \mathrm{ppm}$ respectively (table 1).

The mean levels of manganese in water samples collected from poultry farms at Dairut, Elkosya, Manfalute, Abnob, Elfath, Banygalb, Elbadary, Sahel selem and Abotig were $0.017 \pm 0.01,0.10 \pm 0.069$, $0.07 \pm 0.03, \quad 0.03 \pm 0.002, \quad 0.02 \pm 0.009, \quad 0.03 \pm 0.014$, $0.44 \pm 0.12, \quad 0.17 \pm 0.069$ and $0.19 \pm 0.99 \mathrm{ppm}$ respectively (table 1 ).

The mean levels of nitrites in water samples collected from poultry farms at Dairut, Elkosya, Manfalute, Abnob, Elfath, Banygalb, Elbadary, Sahel selem and Abotig were $1.19 \pm 0.83, \quad 0.71 \pm 0.28, \quad 0.34 \pm 0.07$, $0.64 \pm 0.001, \quad 3.77 \pm 0.59, \quad 0.1 \pm 0.004, \quad 0.49 \pm 0.16$ $1.11 \pm 0.21$ and $0.15 \pm 0.03 \mathrm{ppm}$ respectively (table 1 ). 
Table 1: Mean levels of heavy metals and nitrites ( $\mathrm{ppm})$ in water samples collected from different poultry farms at some Assiut cities.

\begin{tabular}{|c|c|c|c|c|c|c|c|c|c|c|}
\hline & $\begin{array}{c}\text { Permissible } \\
\text { limit } \\
(\mathrm{WHO})\end{array}$ & Dairut & Elkosya & Manfalute & Abnob & Elfath & Banygalb & Elbadary & $\begin{array}{c}\text { Sahel } \\
\text { seleem }\end{array}$ & Abotig \\
\hline Lead & $0.01 \mathrm{mg} / \mathrm{L}$ & $\begin{array}{c}0.370 \pm \\
0.30\end{array}$ & $\begin{array}{c}0.096 \pm \\
0.02\end{array}$ & $\begin{array}{c}0.260 \pm \\
0.10\end{array}$ & $\begin{array}{c}0.09 \pm \\
0.06\end{array}$ & $\begin{array}{c}0.091 \pm \\
0.01\end{array}$ & $\begin{array}{c}0.260 \pm \\
0.21\end{array}$ & $\begin{array}{c}0.330 \pm \\
0.31\end{array}$ & $\begin{array}{c}0.700 \pm \\
0.30\end{array}$ & $\begin{array}{c}0.75 \pm \\
0.320\end{array}$ \\
\hline cadmium & $0.003 \mathrm{mg} / \mathrm{L}$ & $\begin{array}{c}0.0015 \pm \\
0.0010\end{array}$ & $\begin{array}{c}0.0007 \pm \\
0.0002\end{array}$ & $\begin{array}{c}0.001 \pm \\
0.0005\end{array}$ & $\begin{array}{c}0.0006 \pm \\
0.0002\end{array}$ & $\begin{array}{c}0.0004 \pm \\
0.0002\end{array}$ & $\begin{array}{c}0.001 \pm \\
0.0003\end{array}$ & $\begin{array}{c}0.0032 \pm \\
0.003\end{array}$ & $\begin{array}{c}0.004 \pm \\
0.002\end{array}$ & $\begin{array}{c}0.0008 \pm \\
0.0004\end{array}$ \\
\hline manganese & $0.5 \mathrm{mg} / \mathrm{L}$ & $\begin{array}{c}0.017 \pm \\
0.01\end{array}$ & $\begin{array}{c}0.10 \pm \\
0.069\end{array}$ & $\begin{array}{c}0.07 \pm \\
0.03\end{array}$ & $\begin{array}{c}0.03 \pm \\
0.002\end{array}$ & $\begin{array}{l}0.02 \pm \\
0.009\end{array}$ & $\begin{array}{c}0.03 \pm \\
0.014\end{array}$ & $\begin{array}{c}0.44 \pm \\
0.12\end{array}$ & $\begin{array}{c}0.17 \pm \\
0.069\end{array}$ & $\begin{array}{c}0.19 \pm \\
0.99\end{array}$ \\
\hline nitrites & $3 \mathrm{mg} / \mathrm{L}$ & $\begin{array}{c}1.19 \pm \\
0.83\end{array}$ & $\begin{array}{c}0.71 \pm \\
0.28\end{array}$ & $\begin{array}{c}0.34 \pm \\
0.07\end{array}$ & $\begin{array}{c}0.64 \pm \\
0.001\end{array}$ & $\begin{array}{c}3.77 \pm \\
0.59\end{array}$ & $\begin{array}{l}0.1 \pm \\
0.004\end{array}$ & $\begin{array}{c}0.49 \pm \\
0.16\end{array}$ & $\begin{array}{c}1.11 \pm \\
0.21\end{array}$ & $\begin{array}{c}0.15 \pm \\
0.03\end{array}$ \\
\hline
\end{tabular}

\section{DISCUSSION}

Several heavy metals are present in drinking water that play important roles in the body provided their level remains within the specified range recommended by WHO. Now due to the industrialization and rapid urbanization, the problems of pollution have surfaced. So, biological interest in these metals is mainly due to their potential toxicity for man, animals and poultry when they are released into the environment (Jaleel et al., 2001).

In the present study, it was observed that there are increase in the mean levels of lead in water samples collected from poultry farms at Dairut, Elkosya, Manfalute, Abnob, Elfath, Banygalb, Elbadary, Sahel selem and Abotig $0.37 \pm 0.30,0.096 \pm 0.02,0.26 \pm$ $0.10,0.09 \pm 0.06,0.091 \pm 0.01,0.26 \pm 0.21,0.33 \pm$ $0.31,0.70 \pm 0.30$ and $0.75 \pm 0.32$ ppm respectively. The increase in the levels of lead at Elbadary may be attributed to the nearest of River Nile which is the main source of water to high way roods and the effluents of the motor cars.

Nearly similar results were recorded by Salem et al. (2001) who evaluate some chemical pollutants in drinking and surface water, in Upper Egypt. They found that, the mean levels of lead in water samples collected randomly from Aswan, Qena, Assiut and Beni Suef cities were $0.096,0.042,0.06$ and 0.036 ppm respectively and from River Nile water in Aswan, Assiut, Beni Suef regions and Bahr Yousef canal showed values $0.25,0.37,0.12$ and $0.23 \mathrm{ppm}$ respectively.

Also these result were similar to that obtained by Jaleel et al. (2001) who estimated the concentration of heavy metals in drinking water of different localities in district east Karachi and Nadeem et al. (2009) who studied drinking water contamination by chromium and lead in industrial lands of Karachi. They found that water samples had significantly higher of lead level than the maximum acceptable concentration (MAC) in drinking water established by WHO (10ppb). Our results disagree with Ozmen et al. (2004) who demonstrated the concentrations of heavy metals ( $\mathrm{Zn}, \mathrm{Fe}, \mathrm{Mn}, \mathrm{Ni}, \mathrm{Cu}$ and $\mathrm{Pb}$ ) and radioactivity in surface water and sediment of Hazar Lake (Elzig, Turkey) did not exceed permissible limit of lead in water recommended by WHO $(0.01 \mathrm{mg} / 1)$.

All our analyzed water samples had lead values more than the recommended limit $(0.01 \mathrm{mg} / 1)$ by (WHO, 1993). So it can produce many adverse effects in poultry health. Neathery and Miller (1975), stated that, in all domestic species, lead poisoning causes derangement of the central nervous system, gastrointestinal tract, muscular coordination, and red blood cell synthesis

The obtained results revealed that, the cadmium mean values in water samples collected from poultry farms at Dairut, Elkosya, Manfalute, Abnob, Elfath, Banygalb, Elbadary, Sahel selem and Abotig

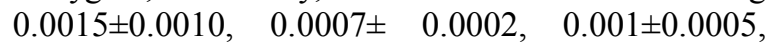
$0.0006 \pm 0.0002, \quad 0.0004 \pm 0.0002, \quad 0.001 \pm 0.0003$, $0.0032 \pm 0.003,0.004 \pm 0.002$ and $0.0008 \pm 0.0004 \mathrm{ppm}$ respectively did not exceed maximum contaminant level of cadmium in drinking water recommended by US EPA $0.005 \mathrm{mg} / 1$ (Stephen, 1998). On the other hand water samples collected from poultry farms at Elbadary and Sahel selem exceed maximum contaminant level of cadmium in drinking water recommended by WHO, 1993 which $0.003 \mathrm{mg} / 1$. 
In the present study the mean values of cadmium in examined water samples were below than values of cadmium in drinking and surface water at Assiut citiy $0.01 \mathrm{mg} / 1$ obtained by Salem et al. (2001). In parallel Jaleel et al. (2001) reported that cadmium and zinc were found to be within the safe limits in drinking water at differefnt localities in district east Karachi.

It was observed that there were an increase in the mean levels of manganese in water samples collected from poultry farms at Elkosya, Elbadary, Sahel selem and Abotig $(0.10 \pm 0.069,0.44 \pm 0.12,0.17 \pm 0.069$ and $0.19 \pm 0.99 \mathrm{ppm})$ respectively, in comparison with lower level in Dairut, Manfalute, Abnob, Elfath and Banygalb $\quad(0.017 \pm 0.01, \quad 0.07 \pm 0.03, \quad 0.03 \pm 0.002$, $0.02 \pm 0.009$ and $0.03 \pm 0.014 \mathrm{ppm})$ respectively. The high concentrations of manganese in water samples collected from Elkosya, Elbadary, Sahel selem and Abotig may be attributed to the supply of these poultry farms with ground water (hand pump water) which characterized by high levels of manganese that represent underground pollution sources. The results in Sahel selem and Abotig were nearly similar to that recorded previously by Salem et al. (2001) who found that, the mean levels of manganese in water samples collected randomly from Assiut city was $0.146 \mathrm{ppm}$ and from River Nile water at Assiut was $0.046 \mathrm{ppm}$.

Our obtained results revealed that manganese levels were between the highest desirable level $0.05 \mathrm{mg} / 1$ recommended by US EPA (Stephen, 1998) and the maximum permissible level $0.5 \mathrm{mg} / \mathrm{I}$ recommended by WHO (1993). Liu et al. (2012) studied the effect of dietary manganese in immune organs of poultry found that excess exposure to $\mathrm{Mn}$ results in metal accumulations in immune organs (spleen, thymus, and bursa of Fabricius). Manganism can disturb the balance of trace elements in immune organs (the Mn content in immune organs increased and $\mathrm{Fe}, \mathrm{Zn}$, and $\mathrm{Ca}$ contents decreased) and induce immune suppression in the molecular level; therefore, the immune function of cocks are suppressed after manganism.

In the present study, it was recorded an increase in The mean levels of nitrites in water samples collected from poultry farms at Dairut, Elfath and Sahel selem $(1.19 \pm 0.83, \quad 3.77 \pm 0.59$ and $1.11 \pm 0.21 \quad \mathrm{ppm}$ respectively) in comparison with lower levels in Elkosya, Manfalute, Abnob, Banygalb, Elbadary and

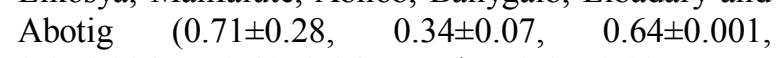
$0.1 \pm 0.004, \quad 0.49 \pm 0.16$ and $0.15 \pm 0.03 \quad \mathrm{ppm}$ respectively). Our obtained results revealed all mean values of nitrites in examained water samples were above the values of nitrites in drinking and surface water at Assiut citiy 0.15 ppm obtained by Salem et al. (2001).
These results were similar to that obtained previously by Bakry et al. (1991) who reported that the nitrites concentration in Kaluob, Benha, Mostorod, Keha, Abou Zabaal, Shubra and EI-Hawamdia were $0.45 \pm 0.2, \quad 0.19 \pm 0.1, \quad 0.41 \pm 0.1, \quad 0.40 \pm 0.1, \quad 1.30 \pm 0.2$, $0.60 \pm 0.1$ and $1.40 \pm 0.4$, respectively. The mean values of nitrites in water samples collected from poultry farms at Dairut, Elfath and Sahel selem $(1.19 \pm 0.83$, $3.77 \pm 0.59$ and $1.11 \pm 0.21 \mathrm{ppm}$ respectively) were above the U.S. drinking water standards $(1 \mathrm{mg} / \mathrm{L})$ recommended by the United States Environmental Protection Agency (Kegley et al., 1998 and Stephen, 1998) and all mean values of nitrites in water samples collected from poultry farms were below the maximum acceptable concentrations (3 $\mathrm{mg} / 1$ ) recommended by WHO (1993) except water samples collected from Elfath which $3.77 \mathrm{ppm}$.

Nitrite is sometimes found at higher concentrations in surface water polluted with nitrogen-containing wastes, such as sewage or run from agricultural lands (Stoskopf, 1993), which may explain the high levels of nitrites in some water samples from Dairut, Elfath and Sahel selem.

Many toxic effects were recorded in poultry after nitrite exposure, Van der Rijt (1989) showed that, nitrite $\left(\mathrm{NO}_{2}\right)$ poisoning occurred in the medium heavy layer parent stock. Nitrite and nitrate $\left(\mathrm{NO}_{3}\right)$ had formed on and in hanging drinking containers, as $\mathrm{NH}_{3}$ dissolved in the drinking water lead to nitrite poisoning which associated with increase mortality of the hens. The feed intake decreased and egg production was reduced. Also Xu et al. (2003) studied the effect of farm compost polluted water in the chicken and found that the nitrosified and acidified compost water induce pharyngo-esophageal, gastric and liver carcinoma in the chicken.

In Conclusion, their were an increase in the mean levels of lead, manganese and nitrite in the drinking water of some poultry farms at Assuit governorate. So restricted measures must be applied to prevent more addition of pollutants especially lead and nitrites to water sources. The River Nile and its tributaries, which considered the main source of water for Egypt, must be also protected from effluents and sewage. Also monitoring chemical contaminants in water sources should be currently conducted to assure health safety for human and animals.

\section{REFERENCES}

Anna, M.F. and Valerie, E.S. (1996): Health Implications of Nitrate and Nitrite in Drinking Water: An Update on Methemoglobinemia Occurrence and Reproductive and Developmental Toxicity. Regulatory 
Toxicology And Pharmacology 23, 35-43 Article No. 0006.

Bakry, H.H.; Ashoub, M.M.; El-Shawarby, R.M. and Abou Salem (1991): Pollution of some water streams in Egypt due to drainage of some industrial establishment. Benha Vet. Med., No.(3)Vol.2.pp.172-177.

Ding, A.H.; Nathan, C.F. and Stuehr, D.J. (1988): Release of reactive nitrogen intermediates and reactive oxygen intermediates from mouse peritoneal macrophages: comparison of activating cytokines and evidence for independent producti0n.J. Immun., 141, 2407-2412.

Douglas-Stroebel, E.; Hoffman, DJ.; Brewer, GL. and Sileo, L. (2004): Effects of leadcontaminated sediment and nutrition on mallard duckling brain growth and biochemistry. Environ Pollut.Sep;131(2): 215-22.

Eckhardt, D.A.V. and Stackelberg, P.E. (1995): Relation of ground-water quality to land use on Long Island, New York. Groundwater 33, 1019-1033.

Hughes, MR.; Smits, JE.; Elliott, JE. and Bennett, DC. (2000): Morphological and pathological effects ingestion on Pekin ducks exposed to saline. J. Toxicol Environ Health A. Dec,15; 61(7): 591-608.

Jaleel, MA.; Noreen, R. and Baseer, A. (2001): Concentration of heavy metals in drinking water of different localities in district east Karachi. J. Ayub Med. Coll Abbottabad. OctDec, 13(4): 12-5.

Kegley, E. Susan, and Andrews, J. (1998): The Chemistry of Water. University Science Books Press, Library of Congress. Landrigan, P.J. and Todd, A.C. (1994): Lead poisoning .West J. Med.: 161 (2): 153-159.

Liu, X.; Li, Z.; Han, C.; Zhang, Z. and Xu, S. (2012): Effects of dietary manganese on $\mathrm{Cu}, \mathrm{Fe}, \mathrm{Zn}$, $\mathrm{Ca}$, Se, IL-1 $\beta$, and IL-2 changes of immune organs in cocks. Biol Trace Elem Res. Sep;148(3): 336-44. doi: 10.

Lockitch, G. (1993): Perspectives on lead toxicity. Clin. Biochem. 26(5): 371-381.

Marquita, K.H. (1997): Understanding environmental pollution. Syndicate Pjsess of Cambridge Univ.

Mary, H.; Ellen, F.; Rodney, S. and Dennis, D. (2008): Adenocarcinoma of the Stomach and Esophagus and Drinking Water and Dietary Sources of Nitrate and Nitrite. Int J Occup Environ Health. 14(3): 193-197.
Nadeem ul-Hag, Arain, MA.; Haque, Z.; Badar, N. and Mughal, N. (2009): Drinking water contamination by chromium and lead in industrial lands of Karachi . J Pak Med Assoc. May, 59(5): 270-274.

Neathery, M.W. and Miller, W.J. (1975): Metabolism and toxicity of Cadmium, Mercury, and Lead in Animals: A Review1. Journal of Dairy Science. Vol. 58, No. 12. 1767-

Ozmen, H.; Kulahcl, F.; Cukuroval, A. and Dogru, M. (2004): Concentrations of heavy metal and radioactivity in surface water and sediment of Hazar Lake (Elazıg, Turkey) Chemosphere 55 (401-408).

Salem, D.A.; Abdou, K.A. and Zaky, Z.M. (2001): Estimation of some chemical pollutants in drinking and surface water in upper Egypt. Ass. Univ. Bull. Environ. Res. Vol.4 No.1, March.

Spalding, R.F. and Exner, M.E. (1993): Occurrence of nitrate in groundwater-a review. Journal of Environmental Quality 22, 392-402.

Stephen, S.O. (1998): Exposure to Contaminants in Drinking Water. CRC Press Boca Raton London New York Washington, D.C.

Stoskopf, M.K. (1993): Water analysis. In: Fish medicine. Craigs Tucker (ed.), W. B. Saunders Company, London.

Szkoda, J. and Żmudzki, J. (2005): Feasibility of microwave digestion for determination of trace elements in biological material by atomic absorption spectroscopy methods. Bromat. Chem. Toksykol., 28: 369-375.

Taupeau, C.; Poupon, J.; Nome, F. and Lefevre, B. (2001): Lead accumulation in the mouse ovary after treatment-induced follicular atresia. Reprod. Toxicol., 15(4): 385-391.

U.S. EPA (1991): National Primary Drinking Water Regulations: Final rule. 40 DFR Parts 141, 142, and 143. Fed. Reg. 56(20), 3526-3597.

Van der Rijt TJ (1989): A case of nitrite poisoning in hens of medium weight laying parent stock. Tijdschr Dierqeneeskd. Apr 15; 114(8).

WHO(1993): Guidelines for drinking water quality, $\left(2^{\text {nd }}\right.$ ed.), Vol. 1, Recommendation, WHO, Genva.

$X u, Z X$.; Tan, JJ.; Chen, FL.; Si, Jh.; Xu, BN.; Li, $G M$. and $W u, X L$. (2003): Farm compost polluted water may induce pharyngoesophageal, gastric and liver carcinoma in the chicken. Zhonghua Zhong Liu Zhi Jul; 25(4): 344-347. 


\section{قياس مستوى بعض الملوثات المعدنيه فى مياه الثرب فى بعض مزارع الدواجن بأسيوط \\ منال محمد سيا ، حسام الدين محمد عمر \\ Email: monna2004@yahoo.com}

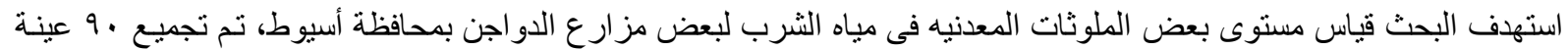

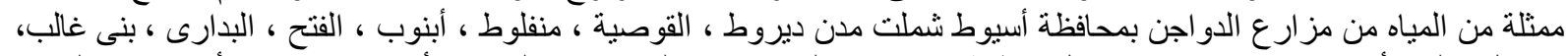

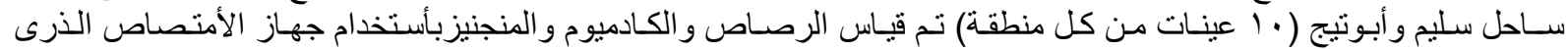

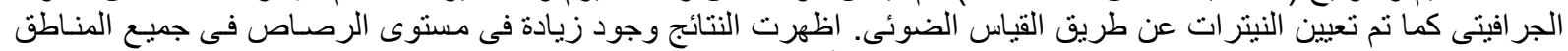

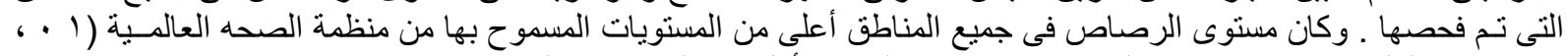

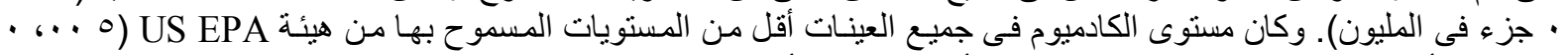

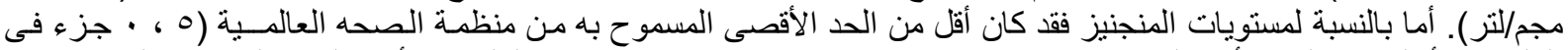

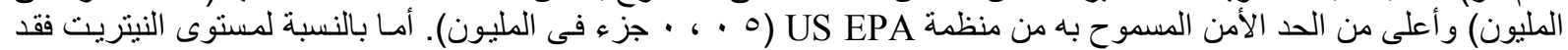

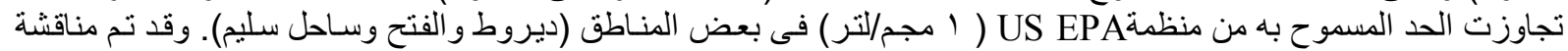
التأثير ات الصحيه الضاره لهذه الملوثات. 